\title{
SONOCHEMICAL MICRONIZATION OF TAXIFOLIN AIMED AT IMPROVING ITS BIOAVAILABILITY IN DRINKS FOR ATHLETES
}

\author{
I.Yu.Potoroko', irina_potoroko@mail.ru, ORCID: 0000-0002-3059-8061, \\ I.V. Kalinina ${ }^{1}$, ORCID: 0000-0002-6246-9870, \\ N.V. Naumenko ${ }^{1}$, ORCID: 0000-0002-9520-3251, \\ R.I. Fatkullin ${ }^{1}$, ORCID: 0000-0002-1498-0703, \\ A.V. Nenasheva ${ }^{1}$, nenashevaav@susu.ru, ORCID: 0000-0001-7579-0463, \\ D.G. Uskova1 ${ }^{1}$ twins.23@mail.ru, ORCID: 0000-0002-9339-6264, \\ S.H. Sonawane ${ }^{2}$, shirish@nitw.ac.in, ORCID: 0000-0002-3201-6731, \\ D.G. Ivanova ${ }^{3}$,dg_ivanova@yahoo.com, ORCID: 0000-0002-8336-2925, \\ M.T.Velyamov4, vmasim58@mail.ru, ORCID: 0000-0002-9248-5951 \\ ${ }^{1}$ South Ural State University, Chelyabinsk, Russian Federation, \\ ${ }^{2}$ National Institute of Technology, Warangal, India, \\ ${ }^{3}$ Medical University, Varna, Bulgaria, \\ ${ }^{4}$ Kazakh Research Institute of Processing and Food Industry, Almaty, Kazakhstan
}

\begin{abstract}
Aim. The aim of this study is to overcome the problem of nutrient bioavailability in drinks for athletes, which is the result of their low permeability in metabolic processes of the body. For this purpose, we used sonochemical micronization of taxifolin - the most effective antioxidant. Materials and methods. To improve taxifolin solubility and bioavailability we used ultrasound treatment, which allowed us to provide taxifolin micronization on the following conditions: 5-, 15- and 25-minute treatment of $20 \pm 2 \mathrm{kHz}$ with radiation intensity of at least $10 \mathrm{~W} / \mathrm{cm}^{2}$, power of 170,400 and $630 \mathrm{~W}$ and temperature within $50{ }^{\circ} \mathrm{C}$. The study was conducted using the following methods: microstructural analysis of native taxifolin and its solutions, including those obtained with sonochemical micronization; analysis of the disperse composition of taxifolin solutions; assessment of the total antioxidant activity of these solutions; assessment of taxifolin solubility and colloidal stability of its solutions. Results. We established that sonochemical micronization allows us to obtain solutions with the predominance of particles of no more than $100 \mathrm{~nm}$. The morphological structure of taxifolin particles has significantly changed, particles are characterized by more homogenous and amorphous structure. We noticed some decrease in antioxidant activity under increased ultrasound exposure. Optimization of ultrasound exposure with the controlling parameter "average particle size" allowed us to establish the most effective mode ( $600 \mathrm{~W}, 18$ minutes), which helped us to improve the colloidal stability of taxifolin solution and taxifolin solubility 6 times in comparison with the control sample. Conclusion. Sonochemical micronization should be regarded as convenient for the development of a new form of taxifolin with increased solubility and bioavailability, which can be used for the production of drinks for athletes.
\end{abstract}

Keywords: taxifolin, sonochemical micronization, solubility, drinks for athletes.

\section{Introduction}

Huge training loads are usually accompanied by the disbalance of reactive oxygen species (ROS) production and adequate antioxidant protection. This unfavorable state can result in cell and tissue damage and is the reason for many physiopathological conditions.

Oxidative stress is the result of the effect of excessive ROS on the body: superoxide, hydrogen peroxide, hydroxy group $\left(\mathrm{OH}^{-}\right)$and hydroperoxide $(\mathrm{ROOH})$. Presence of ROS in cells is inevitable due to the functioning of respiratory chain enzymes and is the result of the activity of oxidants and factors, initiating ROS formation.

During aerobic breathing at least $98 \%$ of the oxygen consumed by cells is subjected to fourelectron reduction by enzymes of the respiratory chain with the formation of a neutral water molecule. At the same time, respiration is accompanied by one-, two- or three-electron reduction with the formation of $\mathrm{H}_{2} \mathrm{O}_{2}$ and $\mathrm{O}_{2}$.

This is the paradox of aerobic live or "the oxygen paradox": oxygen is essential for 
the majority of organisms, but, at the same time, is dangerous for their existence.

Support of the endogenous antioxidant protection of the body is provided by the introduction of exogenous antioxidant additives into the athlete's diet. As a rule, introduction of high antioxidant products is an effective non-invasive tool for preventing or reducing the consequences of oxidative stress during the training.

Antioxidants block oxidation due to the neutralization of free radicals, however, antioxidants themselves are subjected to oxidation processes, which means that there is a necessity to restore the oxidative resources of the body.

Antioxidants play an important role preventing oxidation processes and diseases connected with oxidative stress. These compounds manifest their activity using several mechanisms: (i) elimination of free radicals, (ii) oxygen absorption or (iii) chelation of metal ions, catalyzing oxidative reactions.

Products of plant origin are the main sources of biologically active substances and antioxidants. They synthesize various polyphenols and, in particular, flavonoids.

Taxifolin is a flavanol, the antioxidant activity of which considerably exceeds many flavonoids and has attracted increasing attention of many researchers.

The problem of taxifolin application, especially as a drink component, is connected with its low bioavailability and water solubility. This means that biological effects of taxifolin obtained in vitro cannot be reproduced in vivo $[3,14,21]$. Low solubility (approximately $20 \mathrm{mg} / 1$ in water at environmental temperature) leads to a limited and slow taxifolin absorption restricting its bioavailability [8, 13, 17, 19, 22]. Moreover, as the majority of flavonoids, taxifolin is chemically and thermolabile and degradates rapidly under alkaline conditions or high temperatures $[1,6$, $9,16,18]$.

The study of different sources regarding the improvement of bioavailability allowed us to establish the best protective approaches to elimination of the restrictions connected with extremely low absorption and bioavailability of biologically active substances.

Obtaining of biologically active substances of micron or submicron sizes is one of the directions for creating highly effective forms in terms of bioavailability. Micronization allows to improve significantly the absorption, bioavailability and solubility of hydrophobic substances in water environment. The development of new micronization technologies for biologically active substances is of interest for the creation of special bioavailable forms acting as effective agents.

Overcoming the problem connected with low solubility, stability and permeability of taxifolin determines the aim of our study. For this purpose, we used ultrasound impact based on sonochemical transformations of substances.

\section{Materials and methods}

We studied micronization processes of the biologically active substance of antioxidant activity (taxifolin) with the help of ultrasound impact. Taxifolin effectiveness mostly depends on its bioavailability determined by the speed of its dissolution in water environment and by the stability of the system. We studied various parameters for obtaining stable nanosuspension of taxifolin, including taxifolin concentration, solvent type, power and continuity of ultrasound impact.

As a starting substance we used the extract of the Dahurian larch (Larixgmelinii) in a form of cream-white microcrystalline powder with a mass fraction of taxifolin of no less than $97.0 \%$ (State registration certificate № RU 77.99.11.003.E.018404.05.11 dd. 06.05.2011).

Ultrasound or sonochemical micronization was performed using "VOLNA-L" ultrasound device (certificate number УЗТА-0,63/22-ОЛ, Biysk) with a working tool of a mushroom type.

Micronization was performed during 5, 15 and 25 minutes at a mode of $20 \pm 2 \mathrm{kHz}$ with a radiation intensity of up to $10 \mathrm{~W} / \mathrm{cm}^{2}$, impact power of 170,400 and $630 \mathrm{~W}$ and a temperature of no more than $50{ }^{\circ} \mathrm{C}$. Liquid volume was equal $200 \mathrm{ml}$.

Taxifolin sample solutions were obtained using the following technology:

Control sample - taxifolin weighed amount of $2 \pm 0.001 \mathrm{~g}$ is dissolved in $200 \mathrm{ml}$ of distilled water and blended in a magnetic stirrer during 30 minutes at a temperature of no more than $50{ }^{\circ} \mathrm{C}$.

Model samples - taxifolin weighed amount of $2 \pm 0.001 \mathrm{~g}$ is dissolved in $200 \mathrm{ml}$ of distilled water and exposed to 5-, 15- and 25-minute ultrasound treatment at a temperature of no more than $50{ }^{\circ} \mathrm{C}$ using VOLNA-L ultrasound equipment (УЗТА-0,63/22-ОЛ, Biysk, Russia) at a frequency of $20 \pm 2 \mathrm{kHz}$, radiation intensity of up to $10 \mathrm{~W} / \mathrm{cm}^{2}$, impact power of $170,400,630 \mathrm{~W}$. 


\section{Спортивное питание}

The research methodology is presented in figure 1 in the form of a generalized scheme.

Methods of analysis

Taxifolin mass fraction in dry extracts was established using HPLC method according to a state standard (GOST 33504-2015).

Conditions of analysis:

HPLC analysis mode - isocratic.

Mobile phase: acetonitrile - trifluoroacetic acid $0.03 \%$ (30:70) Speed of mobile phase stream $-1 \mathrm{~cm} / \mathrm{min}$.

Wave length $-290 \mathrm{~nm}$.

Temperature of the column $-20^{\circ} \mathrm{C}$.

Volume of the sample introduced $-0.02 \mathrm{~cm}^{3}$.

Analysis duration $-20 \mathrm{~min}$.

To establish the size of taxifolin particles we used Nanotrac Ultra (Microtrac Inc., the USA) analyzer. The measurements performed with $\mathrm{Na}$ notrac comply with ISO 13321 standard. Nano- trac operation is based on the dynamic light scattering principle when light hits small particles, scatters in all directions and reaches the camera. The particle size is calculated depending on the spectrum widening of the reflected ray. The particle size distribution is based on the spectral analysis of Doppler shifts. The sample in the cell is exposed to laser radiation, while scattered light provoked by Brownian motion is registered at an angle of $180^{\circ}$. The minimum size of registered particles is $0.8 \mathrm{~nm}$, measurement results are precise and reproducible.

The study of the morphological characteristics of taxifolin was conducted using a microscopic method. We prepared uncolored samples of a hanging drop type. The study was conducted with 600X magnification using ALTAMI 136T biological microscope according to the bright field method. The microscope field was fixed

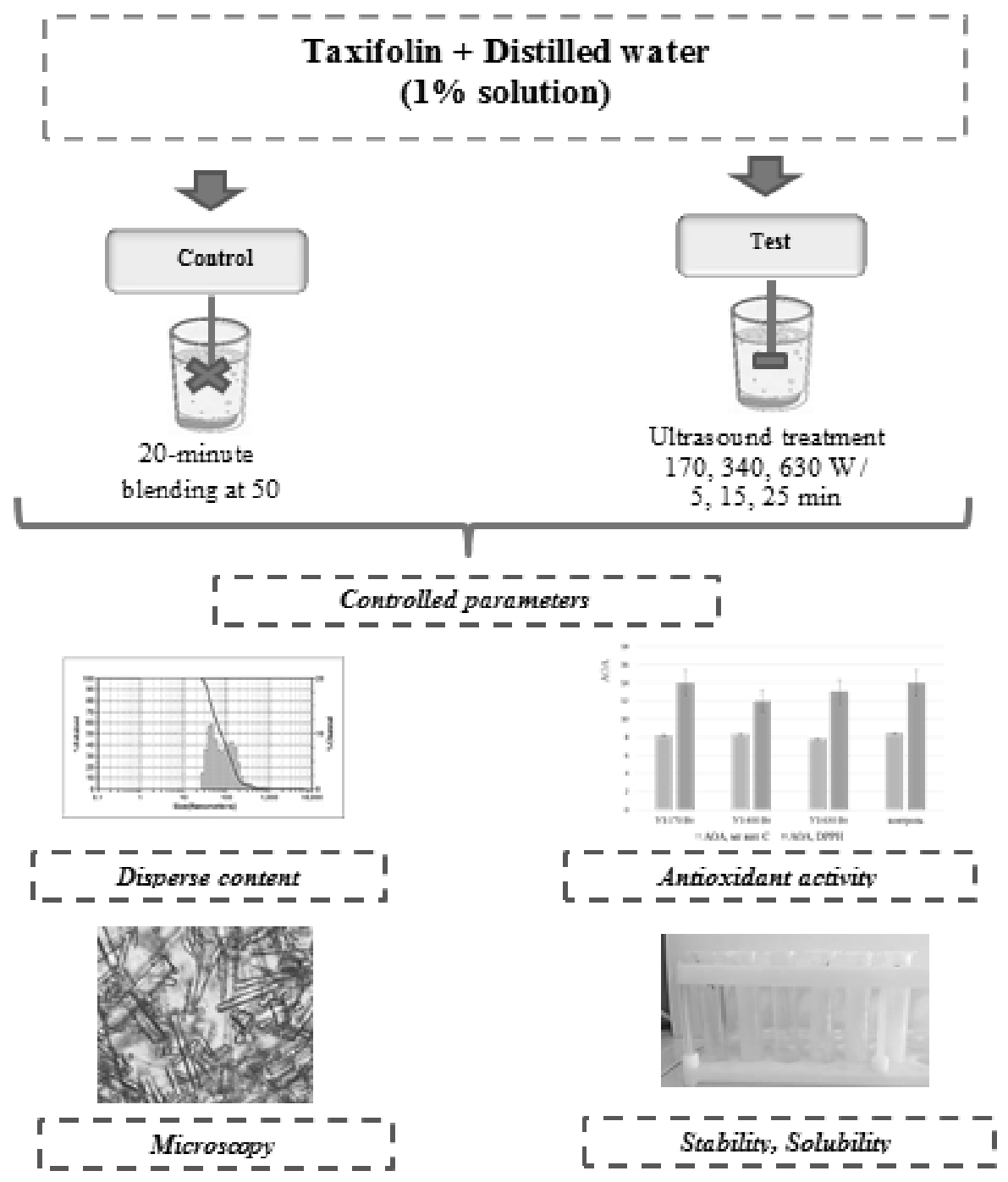

Fig. 1. Generalized experiment scheme 
with the microscope digital camera ЦК13 with USB 2.0 interface.

The morphology of original taxifolin powder was studied using the method of electron scanning microscopy. A small amount of powder was applied to a carbon adhesive tape, which was then covered with a thin gold film using the method of plasma spraying providing required conductivity.

To establish antioxidant activity, we used Expert-006-antioxidants coulometer (registered in a state register under the number СИРФ № 23192), which calculates antioxidant activity in terms of ascorbic acid using the method of coulometric titration.

The titrant is introduced out of the titrating solution and does not react directly with the substance studied. We calculate not the amount of the standard solution (in this case the solution of sulfuric acid with the addition of potassium bromide followed by subsequent dissolution in distilled water) but the current force and time required for contactless titration.

The experiment should be conducted according to the conditions stated in table.

Conditions of the experiment performed with EXPERT - 6011 coulometer

\begin{tabular}{|l|c|}
\hline \multicolumn{1}{|c|}{ Parameter } & Value \\
\hline Air temperature, ${ }^{\circ} \mathrm{C}$ & $15 \ldots 25$ \\
\hline Relative humidity, $\%$ & $<90 \%$ \\
\hline Atmospheric pressure, $\mathrm{kPa}$ & $84.0 \ldots 106.7$ \\
\hline Alternating current frequency, $\mathrm{Hz}$ & $50 \pm 1$ \\
\hline
\end{tabular}

To study the kinetics of physical-chemical processes accompanying nano-cocktails during storage we used the procedures of accelerated aging due to the changes in temperature and light exposure.

The main accent was made on the establishment of the colloidal stability. We worked with the following conditions of accelerated aging: samples were exposed to 48-hour storage at a temperature of $57^{\circ} \mathrm{C}$ under intense light with a spectral characteristic of daylight, then they were exposed to 24-hour storage at a temperature of $18 \ldots 20^{\circ} \mathrm{C}$.

The colloidal stability was assessed visually. The study was conducted right after the aging procedure.

Taxifolin solubility was assessed by preparing its saturated solution $[2,5,12,19,20,23$, $24]$. The excess amount of taxifolin was placed in $2 \mathrm{ml}$ of water (about $5 \mathrm{~g}$ ) and then exposed to 1-hour blending in a magnetic stirrer at a tempe- rature of no more than $50{ }^{\circ} \mathrm{C}$. After filtration of insoluble substance, the filtrate was evaporated to dryness. We calculated weight of the dry residue with the help of weighing.

Calculations and graphical interpretation of the results were performed using MICROSOFT Office Word XP and Excel XP for Windows XP. The optimal mode of ultrasound exposure was determined with the help of 2 factor regression analysis performed in MatCad 2000 program with adequacy checking according to a Fisher's criterion.

Statistical processing of the results was performed by means of Student's t-test. Significance level of the data obtained was assessed using the methods of mathematical statistics and modern software such as MICROSOFT Office and MatCad. Experiments were carried out 3-5 times for each variant of the experiment and control with a confidence level of 0.95 .

\section{Results and discussion}

Ultrasound micronization is associated with a change in the specific surface area of the material, the necessity to reduce the particle size and increase the effective area contacting with a solvent $[4,7,10,13-15]$. To improve taxifolin solubility and bioavailability it is necessary to obtain small and homogenous amorphous nanoparticles. Sonochemical approaches for dispersing homoand heterogenous systems allow us to perform required alignment of the particles of a defined micro- and nanolevel.

At the first stage of the study we established the content of taxifolin in dry extract. What solvent was used for taxifolin extraction and what its residual content in a finished product are the questions of great importance for the experiment. Unfortunately, the taxifolin manufacturer does not indicate these data, which can affect negatively micronization and taxifolin bioavailability.

Highly-performance liquid chromatography (HPLC) (fig. 2) revealed one intensive taxifolin peak and several peaks of process impurities, which were characterized by both smaller and longer retention time. However, the total concentration of substances determining chromatogram peaks did not exceed $1 \%$, which generally indicates a high level of purification of taxifolin extract.

The morphological analysis of taxifolin powder with electron scanning microscopy revealed that the original substance is quite heterogeneous in terms of the size and structural characteristics of particles (fig. 3). 


\section{Спортивное питание}

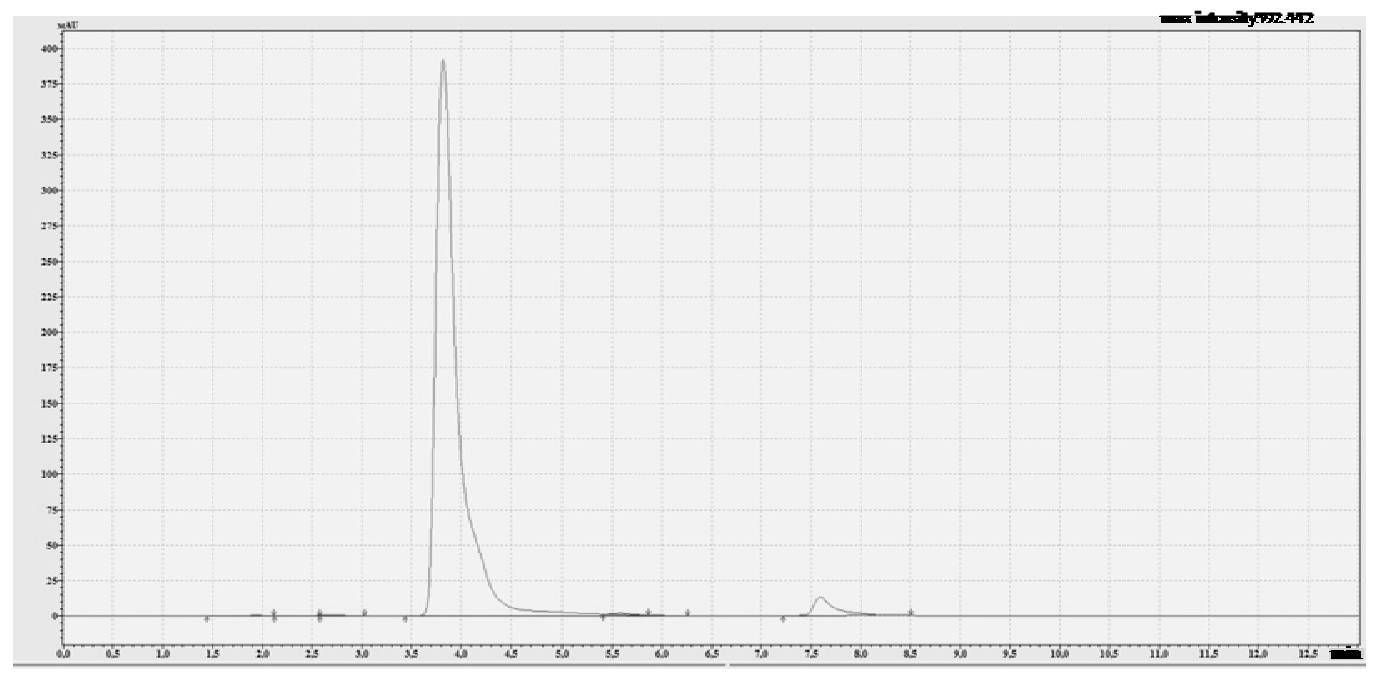

Fig. 2. Taxifolin chromatogram

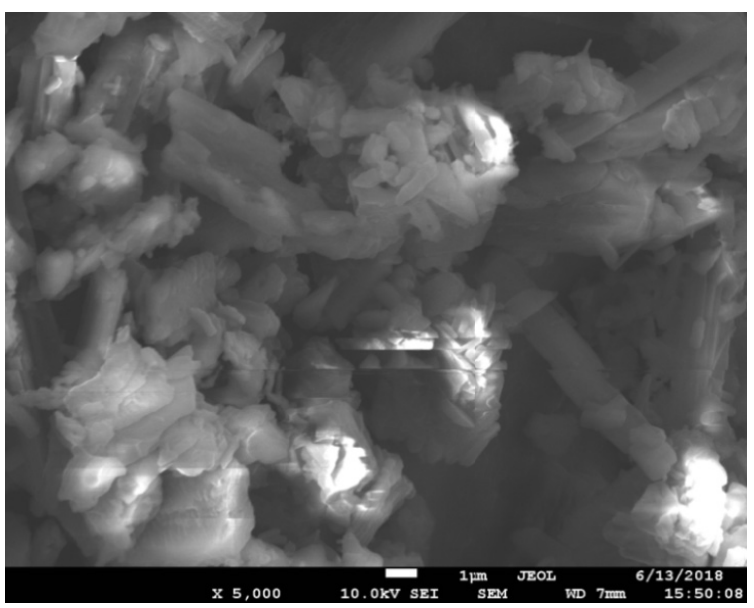

a)

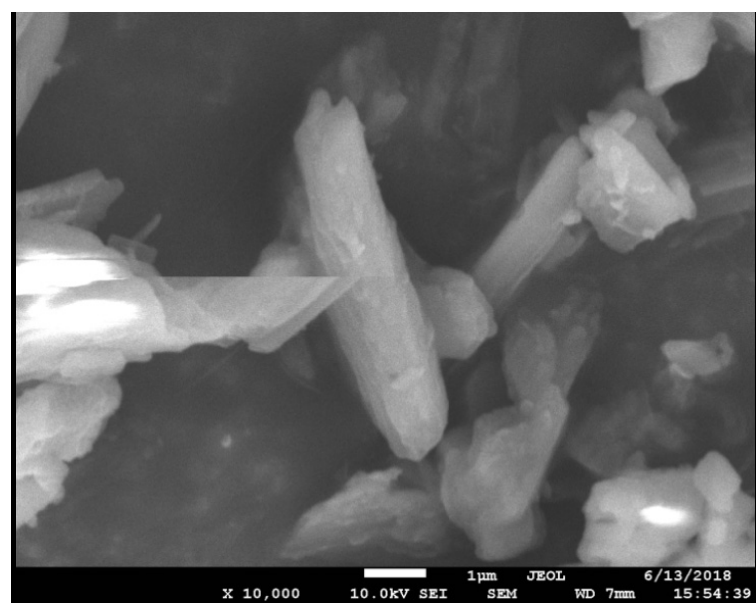

b)

Fig. 3. SEM of the microphotography of the original $98.9 \%$ taxifolin substance: $a-5000 \times$ magnification; $b-10000 \times$ magnification

The figure reveals that the sample studied looks like the accumulation of sufficiently large crystalline particles prone to agglomeration. Taxifolin structure is characterized by the presence of particles of different shapes and structures.

At the next stage we assessed the effect of taxifolin micronization on the morphology and physical-chemical properties of taxifolin.

The study of the disperse composition of taxifolin model samples in comparison with the control sample revealed that micronization together with ultrasound exposure determine changes in the state of the disperse system of taxifolin solutions (fig. 4). The increase in the duration of ultrasound exposure results in the alignment of the particle sizes. In the control sample there is a predominance of the particles of a size range of about
$700 \mathrm{~nm}$ and there are certain particles of more than $3000 \mathrm{~nm}$. Under 15-minute ultrasound exposure of $630 \mathrm{~W}$ the disperse composition changes: there are particles of two fractions - $136 \pm 10 \mathrm{~nm}-$ $45,5 \%$ and $47 \pm 5 \mathrm{~nm}-54,5 \%$. The increase in the duration of ultrasound exposure does not lead to a significant decrease in particle size.

Results of the microscopy of taxifolin water solutions also reveal that ultrasound exposure allows changing taxifolin morphology: particles become smaller and transit to an amorphous state with increasing power and duration of ultrasound exposure (fig. 5).

For the optimization of time and energy costs on ultrasound exposure we conducted a 2-factor planning. The time and power of ultrasound exposure were used as variable factors. 


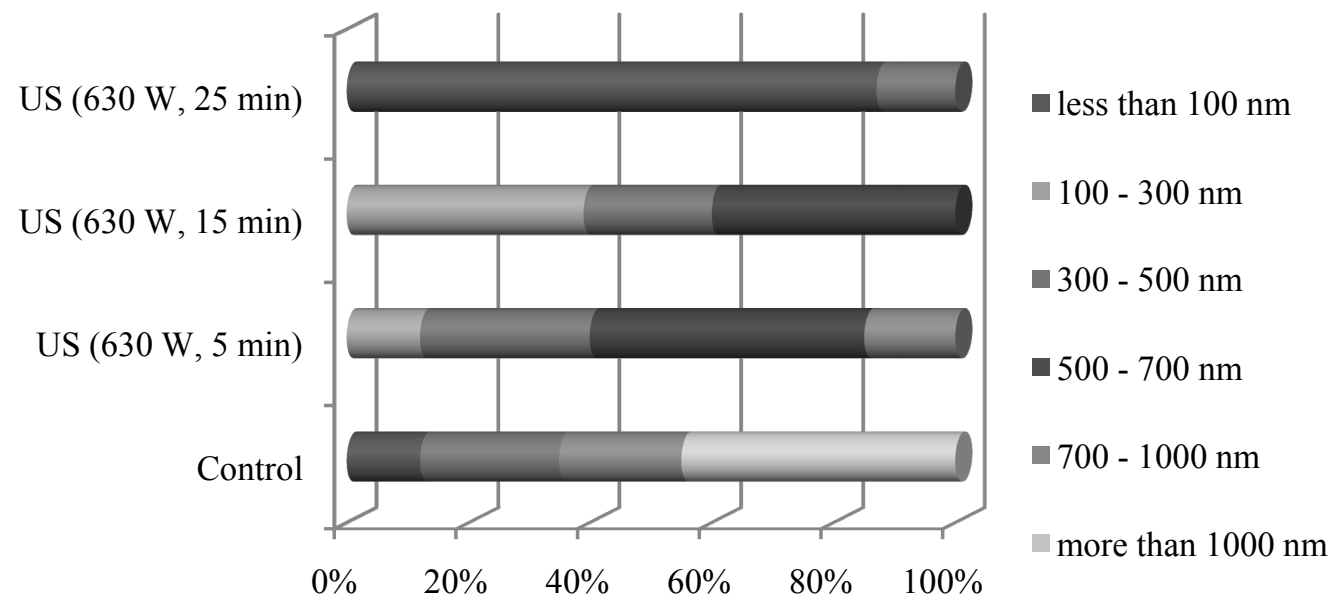

Fig. 4. Correlation of different particle fractions in taxifolin solutions

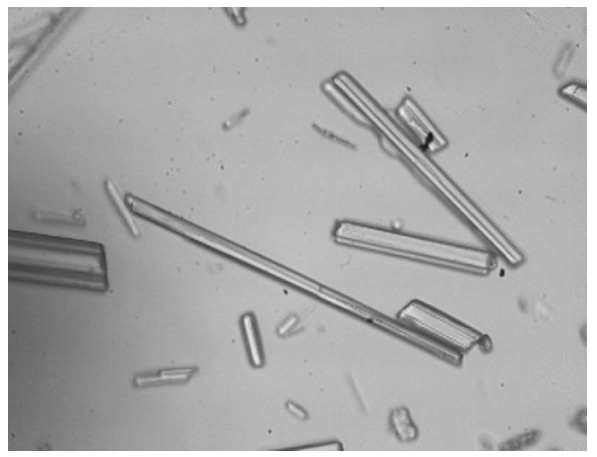

a)

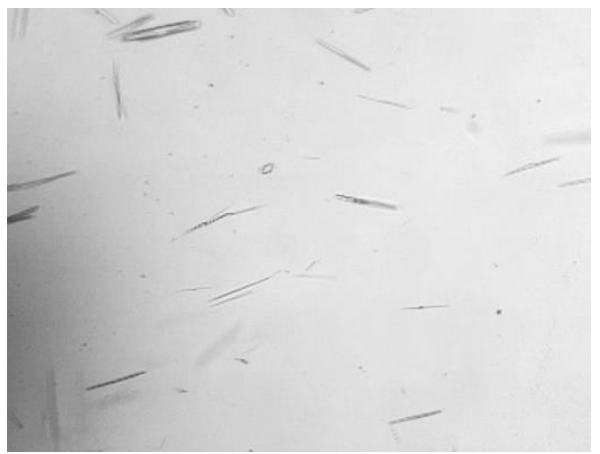

c)

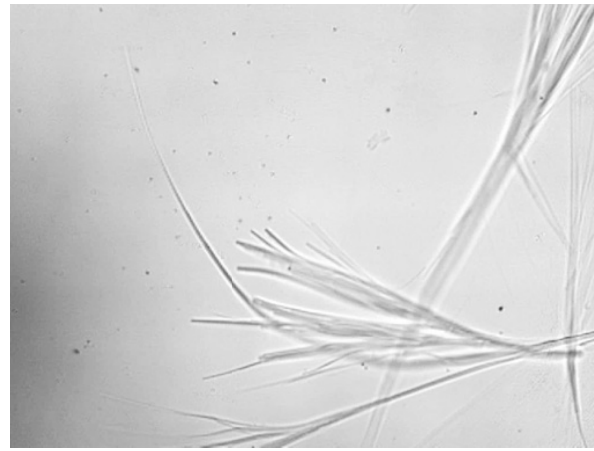

b)

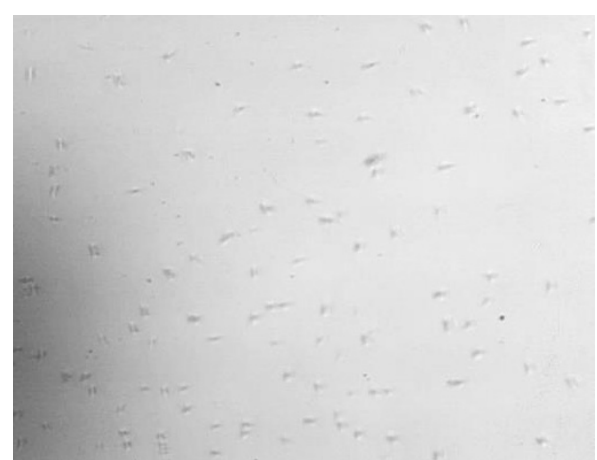

d)

Fig. 5. Microscopy of taxifolin solutions (hanging drop sample, 640x magnification): a - control; b - $630 \mathrm{~W}$ ultrasound exposure, $5 \mathrm{~min}$; c - $630 \mathrm{~W}$ ultrasound exposure, $15 \mathrm{~min}$; d- $630 \mathrm{~W}$ ultrasound exposure, $25 \mathrm{~min}$

The size of taxifolin particles in solutions calculated as a weighted average of the disperse analysis was regarded as a controlled parameter.

Taking into account technical capacities of the ultrasound equipment and physical sense of the values, we established the optimal parameters of ultrasound treatment at a level of $600 \mathrm{~W}$ and 12 minutes (fig. 6).

Antioxidant activity of the solutions obtained has not significantly changed in comparison with the control sample (fig. 7). We registered a certain tendency connected with a decrease in total antioxidant activity under the increase of power. The loss in antioxidant activity between the solutions exposed to 15 -minute ultrasound treatment of 170,400 and $630 \mathrm{~W}$ was equal $8-15 \%$. At the same time, antioxidant activity of the model sample exposed to 15-minute ultrasound treat- 


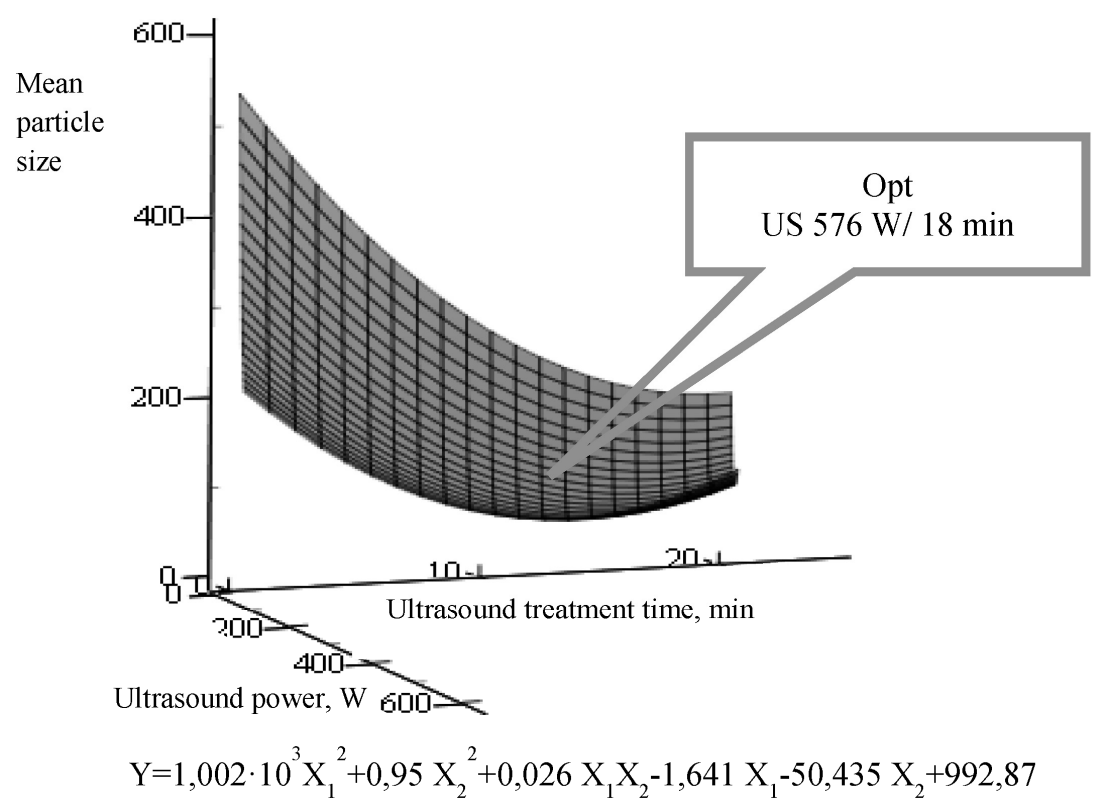

Fig. 6.Modelling of the effect of ultrasound exposure on the formation of taxifolinnanodisperse solution

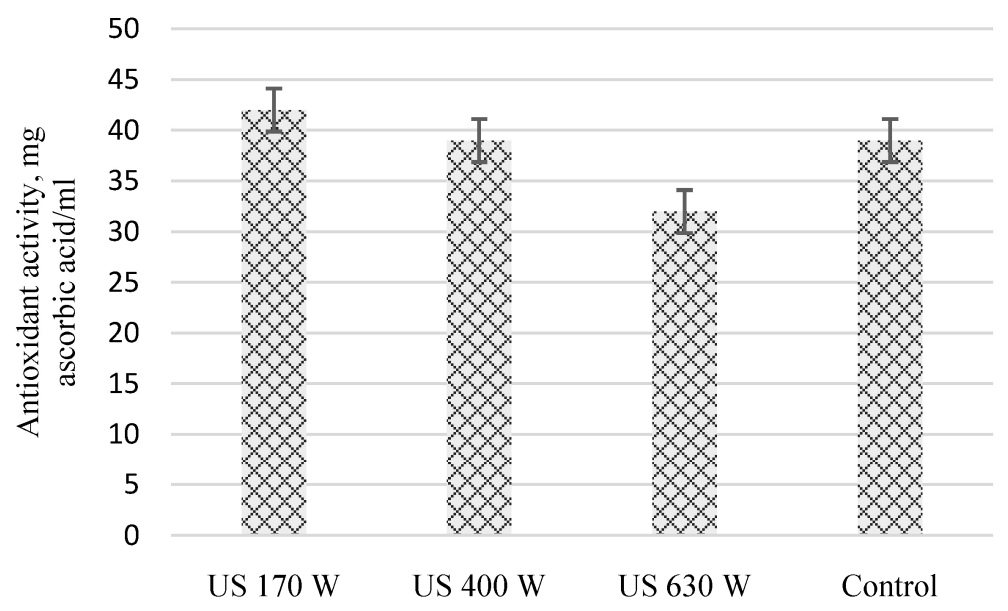

Fig. 7. Antioxidant activity of the solutions studied, $\mathrm{mg}$ ascorbic acid

ment of $170 \mathrm{~W}$ was higher than the antioxidant activity of the control sample. The results obtained require further research on the effect of ultrasound on antioxidant activity of taxifolin solutions.

One of the main characteristics of taxifolin solutions to be used in drinks for athletes is taxifolin solubility and stability of the solutions obtained.

Results of the assessment of taxifolin solubility in water determining its bioactivity and bioavailability revealed that the process of micronization based on the sonochemical approach allows to improve significantly the solubilizing properties of nanodisperse solutions.

Taxifolin solubility in the sample exposed to 18-minute ultrasound treatment of $600 \mathrm{~W}$ was approximately 6 times higher than those of the control sample and equaled $12.8 \mathrm{mg} / \mathrm{l}$ against $2.0 \mathrm{mg} / \mathrm{l}$ in terms of taxifolin.

The assessment of the stability of taxifolin nanodisperse solution in comparison with the control sample also demonstrated good results (fig. 8). In the control sample we registered active behavior of negative colloidal processes with the formation of insoluble taxifolin crystals and turbidity.

The solution of micronized taxifolin almost preserved its colloidal stability after accelerated aging. We registered insignificant loss in solution transparency. 


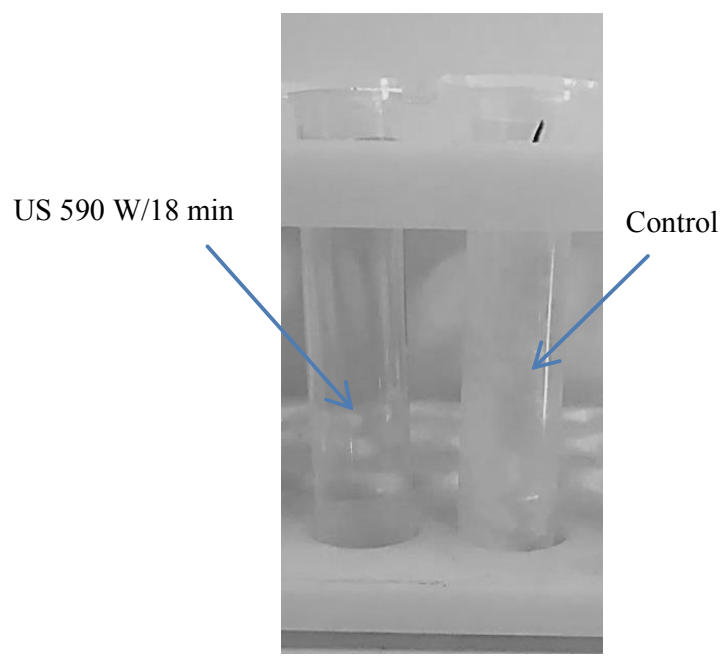

a)

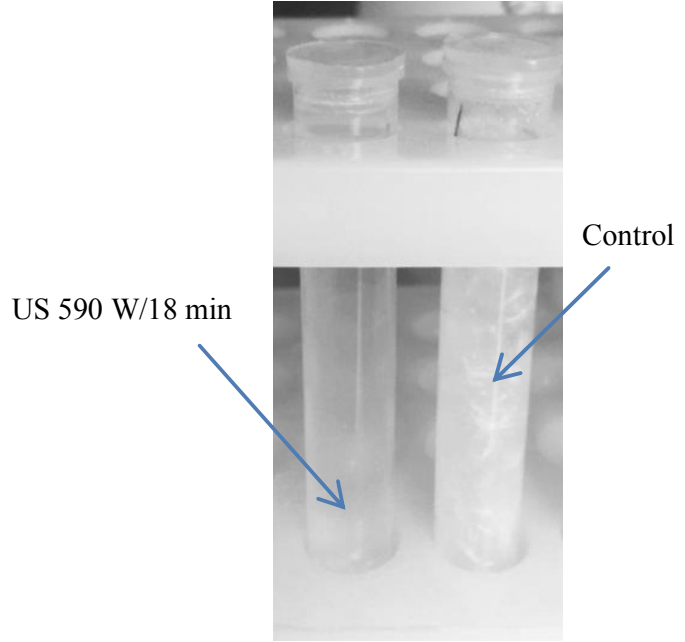

b)

Fig. 8. Assessment of the stability of taxifolin solutions in the conditions of accelerated aging: $a$ - just prepared solution; $b$ - after aging

In general, results of the assessment of taxifolin solutions stability prove its practicability for the application as a part of cloudy drinks for athletes.

\section{Conclusion}

The studies demonstrated that stable taxifolin solutions with increased solubility and potential bioavailability can be successfully obtained with sonochemical micronization. Ultrasound treatment allows to improve significantly the solubility and colloidal stability of taxifolin in water without significant loss in its antioxidant activity.

Therefore, sonochemical micronization should be regarded as an important step in the development of a new taxifolin structure with increased solubility and bioavailability, which can be used in drinks for athletes both within the scope of biomedicine and food industry.

\section{References}

1. Abad-Garcia B., Garmon-Lobato S., Berrueta L.A. Afragmentation Study of Dihydroquercetin Using Triple Quadrupole Mass Spectrometry and Its Application for Identification of Dihydroflavonols in Citrus Juices. Rapid Commun. Mass Spectrom., 2009, vol. 23, pp. 2785-2792. DOI: $10.1002 / \mathrm{rcm} .4182$

2. Alexander N., Shikova O., Pozharitskaya N. et al. Nanodispersions of Taxifolin: Impact of Solid-State Properties on Dissolution Behavior. International Journal of Pharmaceutics, 2009, vol. 377, pp. 148-152. DOI: 10.1016/j.ijpharm.2009.04.044
3. Beckman K.B., Ames B.N. Endogenous Oxidative Damage of mtDNA. Mutation Research. Fundamental and Molecular Mechanisms of Mutagenesis, 1999, vol. 424, pp. 51-58. DOI: 10.1016/S0027-5107(99)00007-X

4. Fatkullin R., Popova N., Kalinina I. et al. Application of Ultrasound Waves for the Improvement of Particle Dispersion in Drinks. Agronomy Research, 2017, vol. 15, pp. 1295-1303.

5. Gao L., Liu G., Wang X. et al. Preparation of a Chemically Stable Quercetin Formulation Using Nanosuspension Technology. International Journal of Pharmaceutics, 2011, vol. 404, pp. 231-237. DOI: 10.1016/j.jpharm.2010.11.009

6. Krasulya O., Bogush V., Trishina V., Potoroko I. et al. Impact of Acoustic Cavitation on Food Emulsions. Ultrasounds Sonochemistry, 2016, vol. 30, pp. 98-102. DOI: 10.1016/j.ultsonch.2015.11.013

7. Krasulya O., Shestakov S., Bogush V. et al. Applications of Sonochemistry in Russian Food Processing Industry. Ultrasounds Sonochemistry, 2014, vol. 21, pp. 2112-2116. DOI:10.1016/j.ultsonch.2014.03.015

8. Lee C.W., Park N.H., Kim J.W. et al. Study of Skin Anti-Ageing and Anti-Inflammatory Effects of Dihydroquercetin, Natural Triterpenoids, and Their Synthetic Derivatives. Bioorg. Khim., 2012, vol. 38, pp. 374-381.

9. Ley R., Lozupone C.A., Hamady M. et al. Worlds Within Worlds: Evolutionof the Vertebrate Gut Microbiota. Nat. Rev. Microbiol., 2008, vol. 6, pp. 776-788. DOI: 10.1038/nrmicro1978

10. Liang L., Gao C., Luo M. et al. Dihy- 


\section{Спортивное питание}

droquercetin (DHQ) Induced HO-1 and NQO1 Expression Against Oxidative Stress Through the Nrf2-Dependent Antioxidant Pathway. J. Agric. Food Chem., 2013, vol. 61, pp. 2755-2761. DOI:10.1021/jf304768p

11. Mittler R. Oxidative Stress, Antioxidants and Stress Tolerance. Trends in Plant Science, 2002, vol. 7 (9), pp. 405-410. DOI: 10.1016/S1360-1385(02)02312-9

12. Naumenko N.V., Kalinina I.V. Sonochemistry Effects Influence on the Adjustments of Raw Materials and Finished Goods Properties in Food Production. International Conference on Industrial Engineering, 19-20 May 2016, Chelyabinsk, pp. 691-696. DOI: 10.4028/www. scientific.net/MSF.870.691

13. Pyne D.B., West N.P., Cox A.J. Cripps Probiotics Supplementation for Athletes - Clinical and Physiological Effects. Eur J Sport Sci., 2015, vol. 15, pp. 63-72. DOI: 10.1080/17461391.2014.971879

14. Rasenack N., Müller B.W. Preparation of Microcrystals by in Situ Micronization. Powder Technology, 2004, vol. 143-144, pp. 291-296. DOI: 10.1016/j.powtec.2004.04.021

15. Rogovskii V.S., Matiushin A.I., Shimanovskii N.L. et al. Antiproliferative and Antioxidant Activity of New Dihydroquercetin Derivatives. Eksp. Klin. Farmakol., 2010, vol. 73, pp. 39-42.

16. Scalbert A., Williamson G. Dietary Intake and Bioavailability of Polyphenols. Journal of Nutrition, 2000, vol. 130 (8), pp. 2073-2085. DOI: $10.1093 / \mathrm{jn} / 130.8 .2073 \mathrm{~S}$

17. Teselkin Y.O., Babenkova I., Kolhir V. et al. Dihydroquercetin as a Means of Antioxidative Defence in Rats with Tetrachloromethane Hepatitis. Phytother. Res., 2000, vol. 14, pp. 160-162. DOI: 10.1002/(SICI)1099-1573 (200005)14:3<160::AID-PTR555>3.0.CO;2-Y
18. Wang Y., Wang C., Zhao J., Ding Y. et al. A Cost-Effective Method to Prepare Curcumin Nanosuspensions with Enhanced Oral Bioavailability. Journal of Colloid and Interface Science, 2017, vol.485, pp.91-98. DOI: 10.1016/j.jcis.2016.09.003

19. Weidmann A.E. Dihydroquercetin: More Than Just an Impurity? Eur. J. Pharmacol., 2012, vol. 684, pp. 19-26. DOI: 10.1016/j.ejphar. 2012.03.035

20. Xia D., Quan P., Piao H. et al. Preparation of Stable Nitrendipine Nanosuspensions Using the Precipitation-Ultrasoundation Method for Enhancement of Dissolution and Oral Bioavailability. European Journal of Pharmaceutical Sciences, 2010, vol. 40, pp. 325-334. DOI: 10.1016/j.ejps.2010.04.006

21. Yanga L.-J., Chenb W., MabSh.-X. et al. Host-Guest System of Taxifolin and Native Cyclodextrin or Its Derivative: Preparation, Characterization, Inclusion Mode, and Solubilization. Carbohydrate Polymers, 2011, vol. 85, pp. 629637.DOI: $10.1016 /$ j.carbpol.2011.03.029

22. Zhang Z.R., Zaharna A., Wong M. et al. Taxifolin Enhances Andrographolide-Induced Mitotic Arrest and Apoptosis in Human Prostate Cancer Cells via Spindle Assembly Checkpoint Activation. PLoS, 2013, vol. 8, p. 54577. DOI: 10.1371/journal.pone.0054577

23. Zu S., Yang L., Huang J. et al. Micronization of Taxifolin by Supercritical Antisolvent Process and Evaluation of Radical Scavenging Activity. Int. J. Mol. Sci., 2012, vol. 13, pp. 8869-8881. DOI: 10.3390/ijms 13078869

24. Zu Y., Wu W., Zhao X. et al. Enhancement of Solubility, Antioxidant Ability and Bioavailability of Taxifolin Nanoparticles by Liquid Antisolvent Precipitation Technique. International Journal of Pharmaceutics, 2014, vol. 471, pp. 366-376. DOI: 10.1016/j.ijpharm.2014.05.049

Received 19 June 2018 


\title{
СОНОХИМИЧЕСКАЯ МИКРОНИЗАЦИЯ ДИГИДРОКВЕРЦЕТИНА ДЛЯ ПОВЫШЕНИЯ ЕГО БИОДОСТУПНОСТИ В СОСТАВЕ НАПИТКОВ ДЛЯ СПОРТИВНОГО ПИТАНИЯ
}

\author{
И.Ю. Потороко ${ }^{1}$, И.В. Калинина ${ }^{1}$, Н.В. Науменко ${ }^{1}$, Р.И. Фаткуллин ${ }^{1}$, \\ А.В. Ненашева ${ }^{1}$, Д.Г. Ускова', Ш. Сонавайн ${ }^{2}$, Д. Иванова ${ }^{3}$, М.Т. Велямов \\ ${ }^{1}$ Южно-Уральский государственный университет, г. Челябинск, Россия \\ ${ }^{2}$ Национальный технологический институт, г. Варангал, Индия \\ ${ }^{3}$ Медицинский университет г. Варна, Болгария \\ ${ }^{4}$ Казахский научно-исследовательский институт перерабатывающей и пищевой \\ промышленности, г. Алматы, Республика Казахстан
}

\begin{abstract}
Целью данного исследование являлось преодоление проблемы биодоступности нутриентов в составе напитков для спортсменов, связанной с их низкой проницаемостью в метаболические процессы организма человека. Для достижения этой цели нами использовался подход сонохимической микронизации дигидрокверцетина (ДГК), наиболее эффективного пищевого антиоксиданта. Материалы и методы исследования. Для повышения растворимости и биодоступности ДГК использовалось ультразвуковое воздействие (УЗВ), позволяющее обеспечить условия микронизации ДГК в режиме $20 \pm 2$ кГц с интенсивностью излучения не менее 10 Вт/см², мощностью воздействия 170,400 и 630 Вт при контроле температуры в пределах $50{ }^{\circ} \mathrm{C}$, в течение 5,15 и 25 мин. Исследование выполнено по комплексу показателей, включающих: микроструктурный анализ, нативного ДГК и его растворов, в том числе, полученных методом сонохимической микронизации; определение дисперсного состава растворов ДГК; их общей антиоксидантной активности; установление степени растворимости ДГК и коллоидной стабильности его растворов. Результаты. Установлено, что сонохимическая микронизация ДГК позволяет получить растворы с преобладанием частиц размерного ряда менее 100 нм. Морфологическая структура частиц раствора ДГК, значительно менялась, частицы характеризовались более однородной и аморфной структурой. Было отмечено некоторое снижение АОА при увеличении мощности УЗВ, в пределах 8-15 \%. Процедура оптимизации УЗВ при контролирующем параметре «средний размер частиц» позволила установить наиболее эффективный режим УЗВ (600 Вт, 18 мин), применение которого позволило увеличить коллоидную стабильность раствора ДГК и увеличить растворимость ДГК в 6 раз по сравнению с контролем. Заключение. Метод сонохимической микронизации ДГК следует рассматривать как целесообразный подход в разработке новой формы ДГК с повышенной растворимостью и биодоступностью, который может использоваться при создании напитков для спортсменов.
\end{abstract}

Ключевые слова: дигидроквериетин, сонохимическая микронизация, растворимость, биодоступность, напитки для спортсменов.

Статья выполнена при поддержке Правительства РФ (Постановление № 211 от 16.03.2013 г.), соглашение № 02.A03.21.0011 и при финансовой поддержке государственного задания № 40.8095.2017/БЧ (2017123-ГЗ).

Потороко Ирина Юрьевна, доктор технических наук, профессор, заведующий кафедрой пищевых и биотехнологий, Южно-Уральский государственный университет. 454080, г. Челябинск, проспект Ленина, 76. E-mail: irina_potoroko@mail.ru, ORCID: 0000-0002-3059-8061.

Калинина Ирина Валерьевна, кандидат технических наук, доцент кафедры пищевых и биотехнологий, Южно-Уральский государственный университет. 454080 , г. Челябинск, проспект Ленина, 76. ORCID: 0000-0002-6246-9870. 


\section{Спортивное питание}

Науменко Наталья Владимировна, кандидат технических наук, доцент кафедры пищевых и биотехнологий, Южно-Уральский государственный университет. 454080, г. Челябинск, проспект Ленина, 76. ORCID: 0000-0002-9520-3251.

Фаткуллин Ринат Ильгидарович, кандидат технических наук, доцент кафедры пищевых и биотехнологий, Южно-Уральский государственный университет. 454080, г. Челябинск, проспект Ленина, 76. ORCID: 0000-0002-1498-0703.

Ненашева Анна Валерьевна, доктор биологических наук, доцент, заведующий кафедрой теории и методики физической культуры и спорта, Южно-Уральский государственный университет. 454080, г. Челябинск, проспект Ленина, 76. E-mail: nenashevaav@susu.ru, ORCID: 0000-0001-7579-0463.

Ускова Дарья Геннадьевна, аспирант кафедры пищевых и биотехнологий, ЮжноУральский государственный университет. 454080, г. Челябинск, проспект Ленина, 76. E-mail: twins.23@mail.ru, ORCID: 0000-0002-9339-6264.

Сонавайн Шириш, доктор философских наук, профессор Департамента химической инженерии, Национальный технологический институт. Индия, Штат Телангана, 506004, г. Варангал. E-mail: shirish@nitw.ac.in, ORCID: 0000-0002-3201-6731.

Иванова Диана, доктор биологических наук, профессор отдела биохимии, молекулярной медицины и нутригеномики лаборатории нутригеномики, функциональных продуктов питания и нутрицевтиков, Медицинский университет. Болгария, 9002, г. Варна, ул. Марин Дринов, 55. E-mail: dg_ivanova@yahoo.com, ORCID: 0000-0002-8336-2925.

Велямов Масимжан Турсунович, заслуженный деятель науки и образования, доктор биологических наук «Биотехнология», профессор, академик Академии сельскохозяйственных наук Казахстана; академик Национальной академии продовольственной безопасности Российской Федерации; заведующий лабораторией «Биотехнология, качества и пищевой безопасности», Казахский научно-исследовательский институт перерабатывающей и пищевой промышленности. Республика Казахстан, 050060, г. Алматы, Бостандыкский район, пр. Гагарина, 238 Г. E-mail: vmasim58@mail.ru, ORCID: 0000-0002-9248-5951.

Поступила в редакцию 19 июня 2018 г.

\section{ОБРАЗЕЦ ЦИТИРОВАНИЯ}

Sonochemical Micronization of Taxifolin Aimed at Improving Its Bioavailability in Drinks for Athletes / I.Yu. Potoroko, I.V. Kalinina, N.V. Naumenko et al. // Человек. Спорт. Медицина. - 2018. - Т. 18, № 3. C. $90-100$. DOI: $10.14529 / \mathrm{hsm} 180309$

\section{FOR CITATION}

Potoroko I.Yu., Kalinina I.V., Naumenko N.V., Fatkullin R.I., Nenasheva A.V., Uskova D.G., Sonawane S.H., Ivanova D.G., Velyamov M.T. Sonochemical Micronization of Taxifolin Aimed at Improving Its Bioavailability in Drinks for Athletes. Human. Sport. Medicine, 2018, vol. 18, no. 3, pp. 90-100. DOI: 10.14529/hsm180309 